\title{
CASH WAQF LINKED SUKUK ALTERNATIVE DEVELOPMENT OF SUSTAINABLE ISLAMIC ECONOMIC DEVELOPMENT SUSTAINABLE DEVELOPMENT GOALS (SDG'S)
}

\author{
Wina Paul \\ Ministry of Religion Regional Office of West Java Province, Bandung \\ austriapaul79@gmail.com \\ Rachmad Faudji \\ Ministry of Finance of the Republic of Indonesia Directorate General of Risk Management and Financing \\ rachmad.faudji@kemenkeu.go.id \\ Hasan Bisri \\ Sunan Gunung Djati State Islamic University, Bandung \\ hasanbisri.uinsgd@gmail.com
}

\begin{abstract}
Economic development itself is defined as a continuous process that has the aim of increasing a country's Gross Domestic Product (GDP) and per capita income of a country's population in the long term which has an impact on various aspects, both economic, social, and science and technology. The purpose of economic development in Indonesia is not only to increase per capita income but also to accelerate economic growth. Technological advances as a result of this development will also improve the quality of human resources, improve community welfare, reduce inequality, and reduce unemployment. The government continues to face various forms of economic development problems in Indonesia, including high unemployment, rampant poverty, high population, inflation resulting in low purchasing power, low productivity resulting in low per capita income, and export commodities dominated by the primary sector. Today, the development of Islamic economics, both in academia and practice, is very important to pay attention to. This is also related to how to develop thoughts and applications of the Islamic economic system in Indonesia. Various perspectives in the field of Islamic economics associated with the Sustainable Development Goals (SDGs) themselves were created to answer the demands of world leadership in overcoming poverty, inequality and climate change in the form of real action. Establish a set of targets that can be applied universally and can be measured in balancing the three dimensions of sustainable development such as environmental, social and economic. Islamic economic objectives in several points of view are philosophical goals consisting of Al-Falah (holistic prosperity) and Maqasid alShariah and operational objectives consisting of increasing faith, creating maslahah, preventing concentration of wealth, and avoiding dangerous activities and even distribution. On the basis of this Islamic economic objective, the response was the issuance of a Cash Waqf Linked Sukuk as a product of the government through the Ministry of Finance to serve as an alternative to increasing Islamic-based economic development. The method used in this article is descriptive qualitative method with literature review. Through this article, we will try to discuss how this cash waqf linked sukuk can be used as an alternative for sustainable Islamic economic development. Sustainable Development Goals (SDG's).
\end{abstract}

Keywords: Cash Waqf, Cash Waqf Linked Sukuk, Islamic Economic Development, Sustainable Development Goals (SDG's). 


\section{A. INTRODUCTION}

The progress and development of a country's economy can be seen from the development carried out by a country. Economic development is a process that aims to increase the per capita income of the population or society in a country in the long term by changing the important characteristics of a society, namely changes in terms of technology, people's mindset and institutions. And accompanied by fundamental changes in the economic structure and distribution of income for the population of a country.

Economic growth in the second quarter of 2020 reached minus 5.32\%. The government also tries to launch various recipes to improve the national economy. President Joko Widodo also emphasized that the draft state budget in 2021 is focused on economic recovery, domestic consumption and investment are expected to be able to bring Indonesia up from the brink of recession.

Economic development according to expert Adam Smith is a process of combining population growth and technological progress (Todaro \& Smith, n.d.). Meanwhile, the definition of economic development according to Prof. Meier is a process of increasing real income per capita over a long period of time. This economic development depends on economic growth, where economic development encourages economic growth and vice versa, accelerates economic growth in the process of economic development.

BPS (Central Statistics Agency) reported that Rl's GDP (Gross Domestic Product) for the second quarter of 2020 was minus $5.32 \%$ in the third quarter minus $3.49 \%$, thus Indonesia entered into a recession in the second quarter. Low household consumption is one of the contributors to this recession. Government consumption was the only source of the economy in terms of expenditure which recorded positive growth. In the third quarter of 2020, government consumption grew 9.76 percent. Meanwhile household consumption is minus 4.04 percent, Gross Fixed Capital Formation (PMTB) or investment is minus 6.48 percent, consumption of non-profit institutions serving households (LNPRT) is minus 2.12 percent, exports are minus 10.28 percent, and imports. minus 21.86 percent.

One measure of the success of economic development is where the real per capita income of a country's population tends to increase continuously in the long run, provided that the number of people living in the absolute poverty line does not increase and the income distribution does not become unequal.

However, the notion of economic development should not only be seen from the increase in per capita income but the quality of good economic development. Economic development is also a process of combining population growth and technological advancement.

Marshal, an expert in Islamic economics, states that the life of this world is controlled by two great powers, namely economy and faith (religion) (S Praja, 2010). Likewise, the Islamic civilization that was glorious in the past could not have been realized without the support of economic strength. Now we need to combine the two forces of human life, namely economy and faith (religion) as an effort to build Islamic economic thought and discipline within the framework of socio-cultural and political development.

Islamic economy should also be able to become an economic trail in sustainable development or what is commonly known as Sustainable Development Goals (SDG's). Of the 17 SDG's, all of them have similarities with the Islamic economy so that the Islamic economy can be used to meet the goals of each SDG's. 
Waqf is one of the potential Islamic economic institutions to be developed, especially in developing countries, waqf can be used as one of the pillars of economic development, one of which is cash waqf (cash waqf). Waqf in the form of money is seen as an option that can make waqf achieve more results. Economically, the reach of waqf and its mobility will be much more evenly distributed among the community. Waqf plays an important role in economic growth and Islamic finance because it has a potential of IDR 300 trillion per year.

The management of cash waqf funds as a tool for investment becomes more attractive, because the benefits or benefits of the investment are in the form of benefits that will be enjoyed by the community everywhere, both locally, regionally and internationally, therefore Cash Waqf Linked Sukuk is present as a government instrument through the Ministry of Finance. to strengthen Islamic-based economic development.

The opportunity for people to get information about waqf is very limited, in our educational institutions, madarasah, schools and Islamic boarding schools, information about waqf is very minimal. Therefore, several things must be addressed to encourage literacy, namely:

First, synergy according to him is very necessary to increase public literacy about waqf. This is called very fundamental, because the level of community participation is highly correlated with the level of literacy.

Second, strengthening nadzir competency standards. This is a very important part of the waqf ecosystem because nadzir has a central role in capitalizing waqf and zakat. For information, nadzir is the party who receives waqf property from wakif to be managed and developed according to its allotment.

Third, the development of waqf instruments such as CWLS (Cash Waqf Linked Sukuk) which was initiated by the Ministry of Finance.

In this article we will discuss how the need for an Islamic economic development system can provide a foundation and contribution to increasing development, especially development with Islamic concepts and thoughts, one of which is about Cash Waqf Linked Sukuk.

\section{B. METHOD}

This study uses a descriptive qualitative approach with a literature review. This method is used to collect data used in social research methodologies to trace historical data.

Judging from the closeness of the content, literature can be classified into two:

1. Primary source.

Primary sources are original articles written by someone who saw, experienced, or worked on their own. This literature material is from diaries (autobiography), theses, dissertations, research reports, and interview results. In addition, the primary source can be in the form of reports on the eyes of a match, population census statistics and so on.

2. Secondary sources

Secondary sources are writings about other people's research, reviews, summaries, criticisms, and similar writings on matters that the author has not directly witnessed or experienced. Secondary literature materials are found in encyclopedias, dictionaries, handbooks, abstracts, indexes, and textbooks (Moleong, 2001). 


\section{RESULT AND DISCUSSION}

\section{Literature Review}

Development according to language is: growing, increasing and developing;(Muşţafâ, et al., 1989) development, increase; increase and become many;(Ibn Manzur \& Al-Fadl Jamaludin bin mukram, 1985) Regarding building, the building process achieves progress, development and so on; or develop all the available resources so that they can multiply.

The definition of development according to economic terms includes: A process that takes place in a sustainable and continuous manner, carried out by a group of individuals, aims to create fundamental changes, with regard to the economic conditions of an underdeveloped society, in order to become a new economic, social, scientific and cultural community group. ; where someone can enjoy life better than before (Hal bawi \& Abd Kharabsyah, 1989). Or in general, development is a process that takes place continuously continuously, carried out by a group of individuals, aiming to achieve progress in life in a quantitative and qualitative manner, so that people can enjoy a better life than before; by developing all the potential and available resources to the maximum.

Meanwhile, the notion of economic development is related to its objectives: it is the development of production and resource wealth owned by the community, by making the most efficient use of economic resources. So that the products produced through development are sufficient for the fulfillment of basic needs and poverty alleviation, as paving the way towards the creation of a prosperous society.

Development activities as the implementation of worship, in accordance with the stipulation that 'every righteous deed is worship', is productive and contributive. With the understanding that everything that is done by the mind and members of the human body that produces goods or services, and has an economic value contribution to the increase in the level of 'prosperity' is included in the category of meaning 'ibâdah'. And efforts and development processes in the Islamic sense, must guarantee the fulfillment of the basic economic needs of every individual member of society; then when some of these basic rights are not fulfilled, it indicates that there is poverty that has not been resolved; due to the 'counterproductive' behavior of some individuals in society, who do not carry out their 'work' functions. Or work, but control the results beyond the portion of their rights which is not in accordance with the level of their contribution in the prosperity process, by taking the results from the contributions of others. In this case there has been a problem in the distribution factor.

Sustainable Development Goals (SDGs) are a global action plan agreed upon by world leaders, including Indonesia, to end poverty, reduce inequality and protect the environment. The SDGs contain 17 Goals and 169 Targets that are expected to be achieved by 2030, consisting of: 1 . No poverty; 2 . Without hunger; 3. Healthy and prosperous life; 4. Quality education; 5. Gender equality; 6. Clean water and proper sanitation; 7. Clean and affordable energy; 8. Decent work and economic growth; 9. Innovation and infrastructure industry; 10. Reducing inequality; 11. Sustainable residential cities; 12. Responsible consumption and production; 13. Handling and climate change; 14. Ocean ecosystems; 15. Land ecosystem; 16. Peace, justice and strong institutions; 17 . Partnerships to achieve goals.

To achieve the 17 Sustainable Development Goals (SDGs) targets, Cash Waqh is here to be part of this SDGs program. Cash waqf or waqf money is waqf in the form of cash that is invested in profitable economic sectors with the provision that a certain percentage is used for social services (Abubakar dkk, n.d.). Cash waqf or also known as cash waqf was first used during the time of Uthman in Egypt, at the end of the 16th 
century (1555-1823M) (Cizakca, 2004). During the Ottoman era in Egypt, the use of Hanafi fiqh in carrying out business and social activities developed. There are three basic reasons why the jurists of the Uthman era constructed cash waqf buildings:

1. The view that movable assets can represent waqf property.

2. Valuation and acceptance of money as a movable asset

3. Approval of cash payments.

The emergence of the cash waqf instrument in Indonesia is in line with new efforts or in other terms a new paradigm of waqf empowerment in Indonesia. This paradigm as stated by Junaidi et al is based on:

1. The principle of immortality of benefits

2. The principle of accountability

3. The principle of management professionalism

4. The principle of justice

The practice of cash waqf in Indonesia is recognized by law. There are at least four regulations governing money waqf, namely Law number 41 of 2004 concerning Waqf, Basic Agrarian Law, Government Regulation Number 46 of 2006 concerning the implementation of Law Number 41 of 2004 concerning Waqf, and Presidential Instruction Number 11991 concerning Compilation of Islamic Law (KHI) (Maksum, 2008).

\section{Economic Development}

Economic development is a process of increasing total income and income per capita by taking into account the increase in population and accompanied by fundamental changes in the economic structure of a country and equal distribution of income for the population of a country. Economic development itself is defined as a continuous process that has the aim of increasing a country's Gross Domestic Product (GDP) and a country's per capita income in the long term which has an impact on various aspects, both economic, social, and science and technology.

Economic development according to experts (Todaro \& Smith, n.d.) Adam Smith is a process combining population growth and technological advancement. Meanwhile, the definition of economic development according to Prof. Meier is a process of increasing real income per capita over a long period of time. This economic development depends on economic growth, where economic development encourages economic growth and vice versa, accelerates economic growth in the process of economic development. One measure of the success of economic development is where the real per capita income of a country's population tends to increase continuously in the long run, provided that the number of people living in the absolute poverty line does not increase and the income distribution does not become unequal.

However, the notion of economic development should not only be seen from the increase in per capita income but the quality of good economic development. Economic development is also a process of combining population growth and technological advancement. including:

In this sense of economic development, there are 3 important elements that need to be highlighted,

1. Development as a development process is a stage that must be undertaken by the community in order to achieve conditions of justice, prosperity and prosperity.

2. Development as an effort to increase per capita income.

3. The increase in income per capita is long term, meaning that on average it increases from year to year. 
There are several kinds of things that can affect economic development and growth, but basically the factors of economic development can be classified into two, for example economic factors and non-economic factors. Here are some of the factors that influence economic development:

1. HR or Human Resources

$\mathrm{HR}$ or Human Resources is the key to the process of economic development. Other resources will mean nothing without the support of HR or potential Human Resources. This is because HR or Human Resources that do not have potential will not be able to manage existing resources optimally.

2. Natural Resources

Natural Resources both in the form of living and in the form of non-living are important things in the economic development of a country. If a country does not have a supply of natural resources or natural resources that can be produced then that country will supply to other countries, if this happens in a long period of time it will be detrimental to the country.

3. Science and Technology

Science is a means that can facilitate processing of natural resources or natural resources.

Technology is a tool that can help people maximize their work

4. The Political Situation

The political situation is one of the factors that influence economic development in a country. If the political condition of a country is unstable with the dismantling of regulations, it will be increasingly difficult for capital to enter the country. With the difficulty of entering capital, production activities will not develop properly.

5. Socio-Culture

The socio-cultural values found in society are equally important in the process of economic development. A country which is inhabited by a population that often experiences conflicts tends to experience stagnation or decline in its development process. On the other hand, a country with a friendly population and upholding equal rights and obligations will encourage stability for investment

6. Government System

A government that adheres to liberalism will free its citizens to do various things, including economic development. A government that adopts a socialist understanding will regulate all aspects of the life of its people.

7. Infrastructure

Complete and equitable infrastructure can encourage the effectiveness and efficiency of production activities carried out by a country. With good infrastructure, every economic actor can achieve ease in carrying out their economic activities. With this convenience, the process of a country's economic development will run better.

Economic development goals are divided into two, namely, short-term development goals and long-term development goals. Following are the objectives of economic development:

1. Improve the quality of life of the community in meeting their basic needs which include food, clothing, shelter, health and security protection from the government.

2. Expanding the distribution of various staple goods.

3. Expanding job opportunities.

4. Improve the quality of education.

5. Increase people's income.

6. Increase the understanding and behavior of society in upholding noble values (religious, social and cultural) and Expanding economic and social options for each individual and the nation as a whole. 
For example: freedom from an attitude of dependence, not only on other people or countries but on any power that has the potential to undermine human values.

\section{Economic Development Elements}

Economic development is defined as a process that causes the per capita income of the population to increase in the long run. There are four important elements related to economic development.

a. Development as a process. This means that development is a stage that must be undertaken by every society or nation.

b. Development as social change. The community as an actor in social change where directly or indirectly social change will have an impact on the smooth running of development or even hinder development.

c. Development as an effort to increase per capita income. As a business, development is an active action that must be taken by a country in order to increase income per capita.

d. The increase in per capita income must take place in the long term. An economy can be stated in a developing state if the income per capita in the long run tends to increase. This does not mean that per capita income has to increase continuously.

Economic development that takes place in a country has both positive and negative impacts. For that you can read the reviews below regarding the positive and negative impacts of economic development.

Dampak Positif Pembangunan Ekonomi

1. Melalui pembangunan ekonomi, pelaksanaan kegiatan perekonomian akan berjalan lebih lancar dan mampu mempercepat proses pertumbuhan ekonomi.

2. Adanya pembangunan ekonomi dimungkinkan terciptanya lapangan pekerjaan yang dibutuhkan oleh masyarakat, dengan demikian akan mengurangi pengangguran.

3. Terciptanya lapangan pekerjaan akibat adanya pembangunan ekonomi secara langsung bisa memperbaiki tingkat pendapatan nasional.

4. Melalui pembangunan ekonomi dimungkinkan adanya perubahan struktur perekonomian dari struktur ekonomi agraris menjadi struktur ekonomi industri, sehingga kegiatan ekonomi yang dilaksanakan oleh negara akan semakin beragam dan dinamis.

5. Pembangunan ekonomi menuntut peningkatan kualitas SDM sehingga dalam hal ini, dimungkinkan ilmu pengetahuan dan teknologi akan berkembang dengan pesat. Dengan demikian, akan makin meningkatkan kesejahteraan masyarakat.

Negative Impact of Economic Development

1. There is economic development that is not well planned, causing environmental damage.

2. Industrialization causes a reduction in agricultural land.

3. The elimination (loss) of natural habitat, be it biological or animal nature.

4. The occurrence of water, air and soil pollution from human indiscipline.

a. The level of economic development greatly influences the progress of a country or region. With a high level of economic development, the state can realize the programs and policies it makes for the advancement of the country itself.

This means that development is not sufficiently measured by per capita income, but the increase must be accompanied by technological changes. Technology has a very important role in increasing production capacity. 


\section{Islamic Economic Development}

Islamic economic development is currently a lot of spotlight and attention from both scientific practitioners and entrepreneurs, this is also related to how to create thoughts related to an Islamic-based economy.

Islamic economics or shari'ah economics have been defined by Muslim scholars with various definitions. This diversity occurs because of differences in the perspective of each expert in their field. The experts' definition of Islamic economics emphasizes the comprehensive character of the subject and is based on the moral values of Islamic economics which aims to examine human welfare achieved through organizing natural resources based on cooperation and participation. This definition has 3 conceptual keys, namely:

1. Al-Falah, namely welfare

2. Resources or resources

3. Cooperation and participation

The foundation of Islamic economic development policies (Suntana, 2010) namely :

1. Tauhid (Tauhidullah)

The foundation of tawheed is a fundamental recognition that all economic resources come from and belong to Allah. The principle of tauhid forms a universal conception that the source of life does not belong to individuals, but belongs to the public (milkullah) and must be accessible to everyone (open access).

2. Justice ('Adalah)

The foundation of justice is the basic principle that the management of economic resources is carried out equally for all people so that each individual has the right to have the same opportunity to participate in and enjoy real economic resources.

3. Sustainability (Istimrariyyah)

The foundation of sustainability requires that the utilization of economic resources be carried out by preserving the function of the source in a sustainable manner. The principle of sustainability is based on the fact that the existence of economic resources is limited in number, while the consumption of them is unlimited. Therefore, efficiency and equity must be the basis for determining the policy for the management and distribution of the economic resources concerned.

Economic policy according to Islam must be supported by four things, including the following:

1. Social responsibility. Social responsibility is not donation in a conventional economic system. Social responsibility according to Islamic economics is a statement that behind the wealth we earn so hard, there are other people's rights and must be given to them.

2. Limited economic freedom by shari'ah. This is based on the theory, the principle of muamalah origin is permissible as long as there is no strong reason to leave it.

3. Multiownership recognition. Islam recognizes private ownership, joint ownership and State ownership.

The pillars of Islamic economic development are as follows:

1. Turn on the human factor

Every economic development policy must motivate and enable each individual to carry out the tasks necessary to improve his economic condition. As for efforts to turn on human factors, namely:

a. Encourage individual motivation.

b. Provide training

2. Reduction of concentration of wealth 


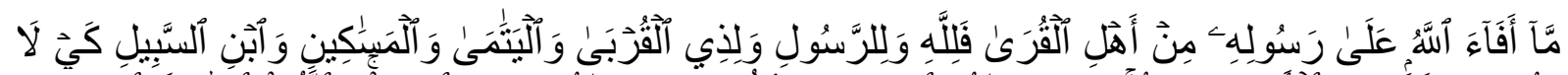

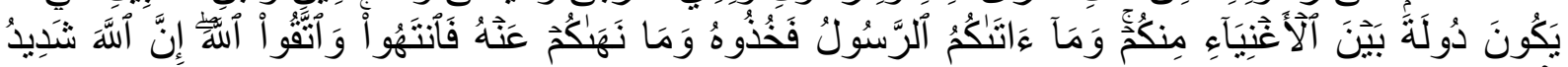

The booty (fai ') from those that Allah gave to His Messenger (who came) from the inhabitants of several countries, is for Allah, Rasul, relatives (Rasul), orphans, poor people and for people who en route, that the treasure may not circulate only among the rich among you. What the Apostle gives you, accept it. Leave what he forbids. And fear Allah. Indeed, Allah is very harsh in his punishment. (Surah Al-Hasyr (59: 7)).

3. Political Economy Restructuring

a. Discipline Waste

The source of Islamic teachings places great emphasis on anyone avoiding extravagant behavior.

b. Priority in spending

Public welfare (al-mashlahah al-ammah) must be the main objective of all State expenditures. All infrastructure projects that realize the common good, promote economic growth and create jobs must be prioritized over financing of projects that play a role.

Islamic political economy experts develop four rules regarding the expenditure of State assets, among which are the following:

1) The expenditure of State assets must be for the general welfare.

2) Overcoming hardship and suffering must take precedence over expenditure on unnecessary development.

3) Expenditures for the public interest should be prioritized over expenditures for limited groups.

4) Each beneficiary must bear the costs.(Durar Al-Hukum Syaah Majalan Al-Hakam Dar Al Kutub Al-IImiyyah Hal 51-57, n.d.)

4. Financial Restructuring

a. Periphery Community Development (Badiyah)

In historical records, Umar bin Khathtab had specifically allocated the proceeds from zakat fitrah and fidyah for the development of their marginalized communities (badiyah) which became the main purpose of distributing these funds.

b. Operation of a Mutual Risk Based Financial System

The Islamic fiscal system requires that the financial system be operated on the basis of joint risk responsibilities. Joint risk bearing accompanied by compensation by financial institutions will reduce the uncertainty of the position of the lower class when they access banking institutions and run the business world.

5. Structural Change

a. Institutional Reform

Institutional reform is an assessment and strategic change about which institutions should be established, which should be streamlined and which should be closed. The assessment of strategic change must be considered based on the priority scale (al-aulawiyat) and factual rationality, as well as when issuing the budget.

b. Policy changes

Too many changes in policies that are not based on the benefit side include in the form of structural waste. Changes too quickly to a policy that has not shown results, including dangerous political bias. 


\section{Sustainable Development (SDGs) and Islamic Economics}

Islam is a perfect religion, as a living system that includes various universal guides. Always provide solutions to problems faced by humans in a holistic manner based on the values contained in the Qur'an and hadith. Islamic teachings are teachings in which there is a balance in both world and hereafter affairs. Islam does not only focus on the hereafter, because in the concept of Islam, the hereafter and the world are one inseparable unity. Therefore, what is received in the afterlife is a consequence of what is done in life.

Currently, various concepts of economic development are being introduced, one of which is the Sutainable Development Goals (SDGs), various perspectives in the field of Islamic economics that are linked to the Sustainable Development Goals (SDGs) themselves are made to answer the demands of world leadership in overcoming poverty, inequality and climate change in the form of real action. Determine a set of targets that can be universally applied and can be measured in balancing the three dimensions of sustainable development such as environmental, social, and economic.

Islamic economic objectives in several points of view are philosophical goals consisting of Al-Falah (holistic prosperity) and Maqasid al-Shariah and operational objectives which consist of increasing faith, creating maslahah, preventing concentration of wealth, and avoiding dangerous activities and equitable distribution. It is important to emphasize the impact aspect. Impact is the most vital thing and is felt directly by the community and the environment. Especially the impact on investment which is the distribution of funds with the aim of generating social and environmental impacts and financial returns. The concept of sustainable development began to emerge when the Brundtland report was released by the World

Commission on Environment and Development (WCED) in 1987. WCED is part of the United Nations or commonly abbreviated as the UN works in the field of environment and economic development.

To understand about sustainable development we must know what is the definition of sustainable development (Sutain-able development). However, to understand this sustainable development each country has a different concept, therefore we depart from a basic socio-economic theory (Mubarok \& Afrijal, n.d.).

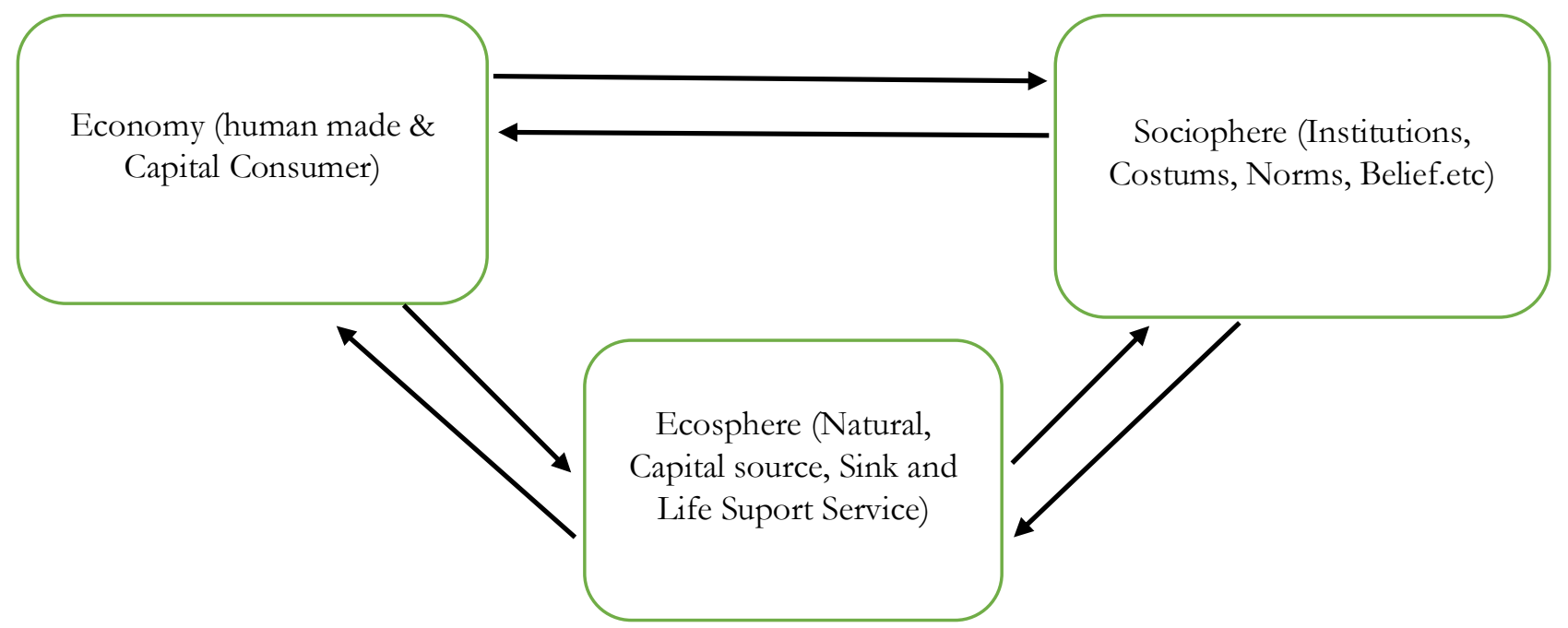

Figure 1: An atomistic mechanism depicting the relationship between the social economy and the environment 
As described by Mulder and Van Den Bergh (Mulder, n.d.) In the figure above, the arrow symbol represents the exchange of materials, energy and information flow between three separate demarcations of the system. This is an improvement to the isolationist model, but it is considered inefficient because the interchangeability of the components mentioned fails to explain the coevolutionary whose scope is economic, social and environmental change. Coevolutionaryii is a term that describes the development of relationships and reciprocal responses that are usually associated with two or more independent systems. A worldview from the coevolutionary explains more real and concrete about the interconnectedness of several systems that make up the global system. Whereas in a broad sense, explaining sustainable development is defined as a country that tries to achieve sustainable development, under a pattern of development that aims to improve the quality of life of every citizen.

One of the goals of Islamic development is Falah or prosperity. The concept of Falah is a concept that explains happiness both in the world and in the hereafter, namely by implementing religious teachings perfectly or kaffah. So that economic development must be able to create a balance between individual interests and the interests of society, of course, which is in line with Islamic teachings.

One alternative to Islamic-based economic development is waqf, in this article we will discuss and limit the cash waqf, cash waqf can be an alternative to increasing Islamic-based economic development.

\section{Cash Waqf and Cash Waqf Linked Sukuk}

Cash waqf is seen as an option that can make waqf achieve more results. Because in cash waqf, money is not only used as a medium of exchange. More than that, money is a commodity that is ready to produce and is useful for the development of other economic activities. Therefore, the same as other commodities, money waqf is also seen as being able to produce something more (Lubis, 2018).

Economically, this cash waqf has a very large potential to be developed, because with this money waqf model the reach and mobility is far more evenly distributed among the community compared to the traditional waqf model (land and building waqf). Because waqf in the form of land and buildings can only be done by families or individuals who are considered wealthy or wealthy, the reach of the waqf giver and the increase in the productivity of waqf assets.

The management of cash waqf funds as an investment tool becomes attractive, because of the benefits or benefits of the investment in the form of benefits that will be enjoyed by people everywhere (both locally, regionally and internationally). This is possible because the investment takes the form of cash that can be diverted anywhere. On the investment side, these waqf funds can be done anywhere without state restrictions. This is expected to be able to increase the harmony between the rich and the poor.

One of the waqf management currently issued by the government is Cash Waqf Linked Sukuk. Cash Waqf Linked Sukuk is a form of social investment in Indonesia where the cash waqf collected by the Indonesian Waqf Board as Nazhir through BNI Syariah and Bank Muamalat Indonesia as Sharia Financial Institutions Receiving Cash Waqf (LKSPWU) will be managed and placed in the State Sukuk or SBSN instrument. (State Sharia Securities) issued by the Ministry of Finance (Kemenkeu). The objectives of developing the Cash Waqf Linked Sukuk are:

1. Part of the development and innovation efforts in the field of Islamic social finance and investment in Indonesia. 
2. Facilitating money waqf so that they can invest money waqf in a safe financial instrument, namely the sukuk of the State.

3. Encourage the consolidation of Islamic social funds to finance various social projects and programs (not government projects / programs through the APBN / APBD).

5. Part of efforts to diversify SBN investors and instruments.

6. Supporting the development of the Islamic financial market, especially the cash waqf industry.

7. Encouraging diversification of the syari'ah banking business by optimizing the role of LKS PWU.

The State Sukuk also has several innovative products that are present from 2018 - 2019, including:

\begin{tabular}{|l|l|}
\hline \multicolumn{1}{|c|}{ State Sukuk Innovation Products } & \multicolumn{1}{c|}{ Implementation Program } \\
\hline Green Sukuk & $\begin{array}{l}\text { Underlying in the form of environmental } \\
\text { conservation and green sukuk activities is the } \\
\text { first issued by a State entity. }\end{array}$ \\
\hline Project SBSN E-Monev & $\begin{array}{l}\text { The online application system for project SBSN } \\
\text { performance management is used for monitoring } \\
\text { reporting and filling of project SBSN Reksus on } \\
\text { line }\end{array}$ \\
\hline Waqf Linked Sukuk & $\begin{array}{l}\text { 1. Is a cash waqf investment in SBSN } \\
\text { distribution of SBSN rewards for social } \\
\text { activities including social infrastructure } \\
\text { which becomes waqf assets. } \\
100 \% \text { repayment of SBSN to temporary } \\
\text { waqf } \\
\text { Innovate again with the emergence of } \\
\text { cash waqf Linked Sukuk Retail }\end{array}$ \\
\hline
\end{tabular}

From year to year the trend of cash waqf has progressed especially in January 2010 with the launch of the Cash Waqf Movement by the President of the Republic of Indonesia, along with data on the trend of cash waqf from 2009-2013: 


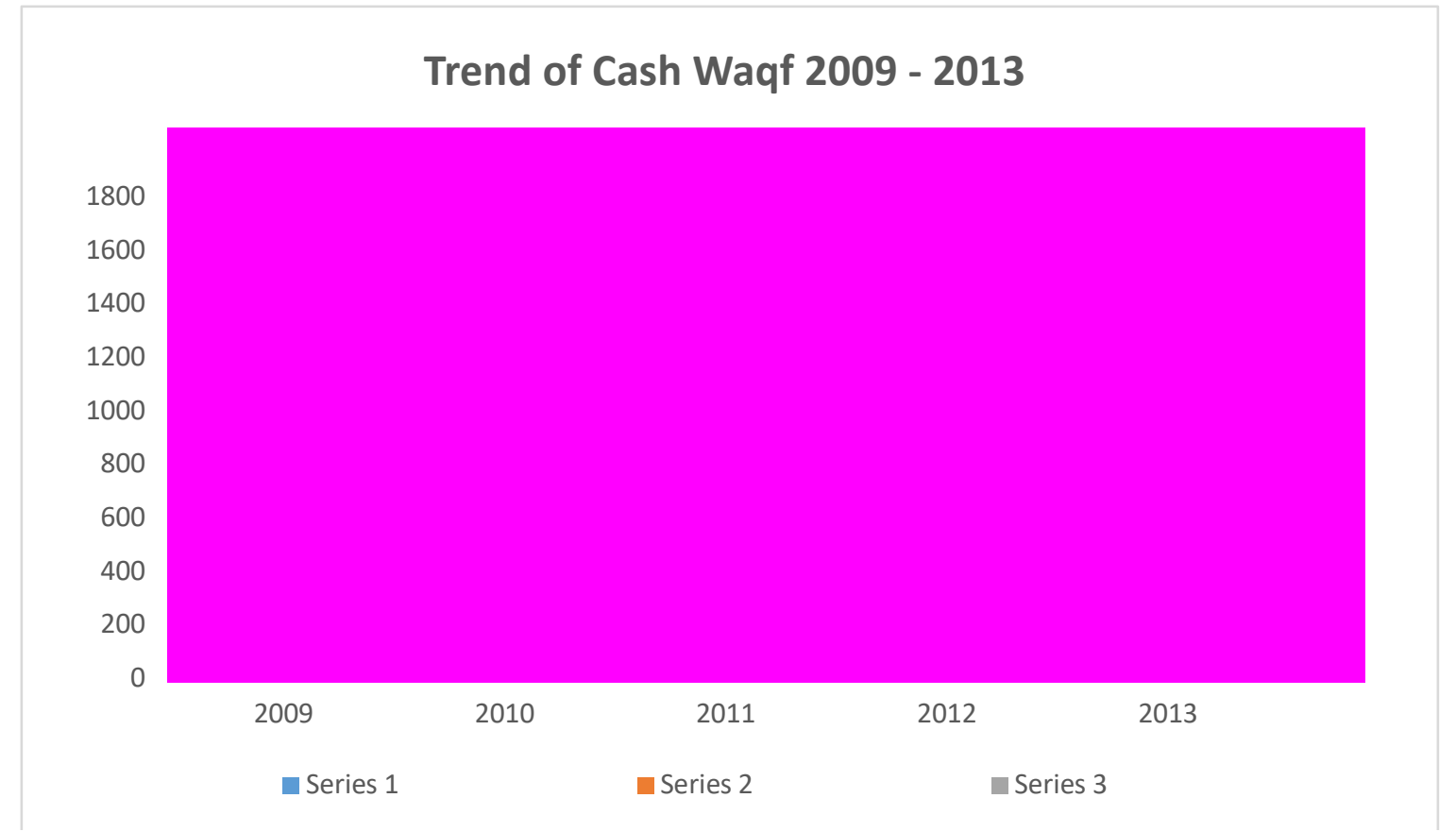

Figure 2: Trends in Cash Waqf, 2009 - 2013

Cash Waqf Linked Sukuk Involves 5 Stakeholders namely:

a. Bank Indonesia as an accelerator in encouraging the implementation of Cash Wagf Linked Sukuk and Custodian Bank.

b. The Indonesian Waqf Board (BWI) as the regulator, leader and Nazhir who manages the Cash Waqf Linked Sukuk.

c. The Ministry of Finance as the SBSN issuer and fund manager in the real sector.

d. Nazhir Waqf Productive as a BWI partner who raises waqf funds.

e. Bank Syariah (Bank Muamalat Indonesia and BNI Syariah) as Sharia Financial Institutions Receiving Cash Waqf (LKS-PWU) and BWI Operational Bank.

The basic concept of a Cash Waqf Linked Sukuk is as follows:

a. This is a concrete manifestation of the strong support and commitment from the authorities, in this case BWI, Ministry of Finance, Ministry of Religion, and BI for development and innovation efforts in the field of Islamic social finance and investment in Indonesia.

b. The government will issue the Sukuk Negara series "Sukuk Waqf" to facilitate BWI and money donors to invest cash waqf in safe financial instruments, namely Sukuk Negara.

c. Through CWLS, cash waqf, both temporary and permanent, will be consolidated and optimized to finance various social projects / activities, including:

1) Construction and development of waqf assets such as madrassas, mosques, health clinics, Islamic boarding schools and other social pre-facilities financed from the discounted sukuk waqf;

2) implementation of non-physical social programs, such as social programs for orphans and the poor, free health services for the poor, economic empowerment of low-income people, and other social programs and financed from monthly sukuk-waqf coupons.

d. The management and implementation of these social projects / activities are carried out by social institutions appointed by BWI, and are not government projects / activities.

Advantages of Cash Waqf Linked Sukuk

1. Facilitating money wakif so that it can be used for productive activities. 
2. Placement of cash waqf in a safe and risk-free instrument, namely Sukuk Negara.

3. The funds will return $100 \%$ to wakif when the SBSN matures.

4. The results of the sukuk-waqf investment are utilized for the formation of new waqf assets and for financing various social activities.

5. Candidates for waqf with a certain amount of cash waqf can propose projects / social activities to be carried out / financed.

6. BWI is exempt from taxation, so the investment returns are competitive.

\section{CONCLUSION}

The existence of cash wagf in Indonesian laws and regulations has shown significant progress in the field of regulations and legislation. This is proven by the regulation of the cash waqf issue in the legislation, namely the issuance of Law Number 41 of 2004, which was followed up by the issuance of government regulation Number 42 of 2006.

Of the many financial concepts launched by the government to boost the economy and to achieve the goals of the SDGs program, various efforts have been made, which ultimately led the government through the Ministry of Religion and the Ministry of Finance to look at cash waqf as an alternative source of state revenue.

From the data that there is income from year to year, waqf money income continues to increase even though previously it had decreased this is due to a lack of understanding and socialization to the public about cash waqf, with the large number of money waqf products issued by the Ministry of Finance in partnership with the Ministry of Religion and BWI Cash Waqf. And the returns from this cash waqf have also been successfully allocated to various sectors such as social, education, infrastructure, health and others. In a state of decline and recession in the Indonesian economy, cash waqf was able to support the development of an Islamic economy. Although there are still many shortcomings.

The presence of Cash Waqf Linked Sukuk can be an alternative in developing cash waqf where one of the urgencies is increasing sustainable Islamic economic development. Cash Waqf Linked Sukuk is one of the Sophiscated products that combines social financial instruments with syari'ah commercial finance which can provide space for people to give alms, Jariyah as wakif, while contributing to the sustainable development of the country's economy.

\section{REFERENCES:}

Abubakar dkk. (n.d.). Filantropi Islam \& Keadilan Sosial: Studi tentang potensi, tradisi, dan pemanfaatan Filantropi Islam di Indonesia. CSR UIN Jakarta.

Cizakca, M. (2004). Ottman Cash Wqf Revisited: The Case of Bursa (1555-1823).

Durar Al-Hukum Syaah Majalan Al-Hakam Dar Al Kutub Al-IImiyyah hal 51-57. (n.d.).

Hal bawi, \& Abd Kharabsyah, Y. wa. (1989). Nahwu Mafbum Atdhal lil altamiyyah al hadisab. Muassasah alRisalah.

Ibn Manzur, \& Al-Fadl Jamaludin bin mukram, A. (1985). Lisan Al-Arab (p. 341). Dar Al saidir.

Lubis, S. D. (2018). Wakaf dan Pemberdayaan Umat (3rd ed., pp. 113-114). Sinar Grafika.

Maksum, M. (2008). Manajemen Investasi Wakaf Uang. Jakarta: UIN Syarif Hidayatullah. 
Moleong, L. J. (2001). Metodologi Penelitian Kualitatif. Remaja Rosda Karya.

Mubarok, S., \& Afrijal, M. (n.d.). Islam dan Sustainable Development, studi Kasus Menjaga Lingkungan dalam Ekonomi Berkeadilan. Dauliyah.

Mulder, V. D. B. (n.d.). The Evolutionary Economic Theiri Of Sustainable Develoment Growth and Cange. 110-134.

Muşţafâ, wa âkhorûn, I., \& al-Wasît, al-M. (1989). Kamus Dewan. Dâr alDa"wah.

S Praja, J. (2010). Politik Ekonomi Islam (I). CV. Pustaka Setia.

Suntana, I. (2010). Politik Ekonomi Islam (I). CV. Pustaka Setia.

Todaro, M. P., \& Smith, S. C. (n.d.). PEMBANGUNAN EKONOMI, edisi 9, jilid 1. Erlangga. https://books.google.co.id/books?id=m8kMk_KbSX4C 